\title{
Presence of Paragonimus species within secondary crustacean hosts in Bogotá, Colombia
}

\author{
Presencia de especies de Paragonimus en huéspedes crustaceos secundarios en Bogotá, Colombia
}

Presença de espécies de Paragonimus em crustáceos hospedeiros secundários em Bogotá, Colômbia

Gillian Phillips ${ }^{1,2 *}$, MPH; David M Hudson², 4, 5, PhD; Jenny J Chaparro-Gutiérrez³, MV, Ms, DrSci.

${ }^{1}$ Georgia State University, Atlanta, Georgia, USA.

${ }^{2}$ The Maritime Aquarium at Norwalk, Norwalk, Connecticut, USA.

${ }^{3}$ Grupo CIBAV, Laboratorio de Parasitología Veterinaria. Escuela de Medicina Veterinaria, Universidad de Antioquia, UdeA. Medellín, Colombia.

${ }^{4}$ Instituto de Ciencias Naturales, Universidad Nacional de Colombia, Bogotá, Colombia.

${ }^{5}$ Atlanta Metropolitan State College, Atlanta, Georgia, USA.

(Received: February 1, 2018; accepted: August 1, 2018)

doi: 10.17533/udea.rccp.v32n2a08

\begin{abstract}
Background: Paragonimus spp. are trematode parasites that infect human populations worldwide. It is believed that infection rates within Asia reach five to ten percent of the total population. Three of the largest areas of possible infection are Asia, Central and South America as well as Africa, where the total population at risk is estimated to be 293 million people. Humans are infected via ingestion of raw or undercooked decapod crustaceans. Objective: To identify the presence of Paragonimus spp. in crabs from Bogotá, Colombia. Methods: The native crab Neostrengeria macropa and the aquatic invasive crayfish Procambarus clarkii in Bogotá, Colombia, were collected from local markets, pet stores and waterways and dissected to assess the presence of Paragonimus spp. Results: The native crab species, . macropa $(\mathrm{n}=29)$ had an infection prevalence of $17.2 \%$, while the invasive crayfish species, $P$. clarkii $(\mathrm{n}=22)$, had a prevalence of $36.4 \%$ combined from both field captured animals and purchased samples. Conclusion: Although the estimated prevalence is lower compared to previous studies in other cities of Colombia, Paragonimus represent a risk to human health.
\end{abstract}

a To cite this article: Phillips G, Hudson DM, Chaparro-Gutiérrez JJ. Presence of Paragonimus species within secondary crustacean hosts in Bogotá, Colombia. Rev Colomb Cienc Pecu 2019; 32(2):150-157.

* Corresponding autor: Gillian Phillips. Georgia State University, Atlanta, Georgia, USA. Tel.: +1- 404-735-2045. E-mail: gillianlynphillips@gmail.com 
Several environmental factors may contribute to the difference in prevalence including collecting season, rainfall, temperature, altitude and the El Niño Southern Oscillation.

Keywords: crabs, invasive species, Neostrengeria macropa, Procambarus clarkii, trematode.

\section{Resumen}

Antecedentes: Los Paragonimus spp. constituyen un grupo de parásitos tremátodos que infectan a humanos en todo el mundo. Se considera que entre 5 y $10 \%$ de la población humana de Asia está infectada. Las áreas con mayor posibilidad de infección son Asia, Centro y Sur América, así como África. Se estima que 293 millones de personas están en riesgo de infección. Los humanos se pueden infectar al consumir crustáceos decápodos crudos. Objetivo: Identificar la presencia de Paragonimus spp. en crustáceos en Bogotá, Colombia. Métodos: Una muestra de cangrejos nativos Neostrengeria macropa y de decápodos invasores Procambarus clarkii fue colectada tanto en mercados locales de Bogotá, como en tiendas de mascotas, ríos, y quebradas. Posteriromente fueron diseccionados para detectar la presencia de Paragonimus spp. Resultados: La prevalencia de la infección en $N$. macropa $(\mathrm{n}=29)$ fue de 17,2\%, y en la especie invasora, $P$. clarkii $(\mathrm{n}=22)$, fue de 36,4\% (porcentaje combinado de los animales colectados en el campo y los comprados en tiendas). Conclusión: Aunque la prevalencia en este estudio fue más baja que la de otras investigaciones relacionadas, se considera que existe riesgo para la salud humana. Es probable que algunos factores medio ambientales hayan contribuido a la diferencia, incluyendo: temporada de colecta, nivel de lluvias, temperatura, altura, y el fenómeno El Niño.

Palabras claves: cangrejos, especie invasora, Neostrengeria macropa, Procambarus clarkii, tremátodo.

\section{Resumo}

Antecedentes: Paragonimus spp. são trematódeos parasitas que infectam populações humanas ao redor do mundo. Acredita-se que as taxas de infecção na Ásia atingem de 5 a $10 \%$ da população. As três maiores áreas de infecção se localizam na Ásia, Américas do Sul e Central e África, onde a população total em risco é estimada em 293 milhões de pessoas. Os humanos são infectados pela ingestão de crustáceos decápodes crus ou mal cozidos. Objetivo: Identificar a presença de Paragonimus spp. em Bogotá, Colômbia. Métodos: Indivíduos de caranguejo nativo Neostrengeria macropa e lagostim aquático invasivo Procambarus clarkii foram coletados em mercados locais, lojas de animais de estimação e cursos de água em Bogotá (Colômbia) e posteriormente dissecados para verificação da presença de Paragonimus spp. Resultados: A espécie de caranguejo nativa $N$. macropa $(\mathrm{n}=29)$ apresentou prevalência de infecção de $17,2 \%$, enquanto a espécie de lagostim invasivo, P. clarkii ( $\mathrm{n}=22$ ), apresentou prevalência de $36,4 \%$, quando combinados os animais capturados em campo e os animais comprados. Conclusão: Embora a prevalência estimada neste estudo foi menor do que a de pesquisas anteriores realizadas em outras cidades da Colômbia, existe um risco para a saúde humana. Há inúmeros fatores ambientais que podem contribuir para a diferença de prevalência, dentre eles: a estação em que a coleta foi realizada, pouca precipitação, temperatura, altitude e a Oscilação Sul-El Niño.

Palabras-chave: caranguejos, espécies invasivas, Neostrengeria macropa, Procambarus clarkii, trematódeos.

\section{Introduction}

Paragonimiasis is a lung infection caused by trematodes of the genus Paragonimus (Braun, 1899). Paragonimiasis is endemic in Asia, Africa, and Central and South America (Davidson, 2005). Infection occurs through consumption of undercooked, raw, or pickled crustaceans (Toledo et al., 2012), which are often aligned with cultural practices or socioeconomic status (Narain et al., 2015). Paragonimus spp. penetrates the gastrointestinal tract and diaphragm, and then matures in the lungs of definitive hosts (Toledo et al., 2012). Clinical symptoms in humans include fever, coughing blood, painful breathing, shortness of breath, and recurrent bacterial pneumonia; chronically infected individuals develop pleural effusion and lung abscesses (Davidson, 2005).

There are numerous mammalian definitive hosts (Liu et al., 2008). Previous studies documented dogs, wild boar, pigs (Kirino et al., 2009), opossum (Little, 1968), foxes, wolves, tigers, lions leopards and civets (Aka et al., 2008) as potential definitive hosts. Apart from raw-infected pork consumption 
(Procoop, 2009), mammals cannot directly infect other mammals, but they can shed eggs into water sources and continuously re-infect those water sources (Liu et al., 2008). In Colombia, Paragonimus caliensis adult trematodes were first described in two species of opossum and in three species of felines, ocelot, margay cat, and jaguar as well as metacercariae being found in the hepatopancreas of crabs (Little, 1968). These definitive hosts allow for maturation of metacercariae and continuation of the life cycle by passing mature oocysts in feces (Liu et al., 2008). Additional identification of mammalian hosts within Colombia would help to identify sources of reinfection in freshwater systems.

Transmission is restricted to areas where the primary intermediate host, molluscs, and secondary intermediate crustacean hosts coexist in freshwater. Eggs are shed into water reservoirs where they hatch and penetrate molluscs such as Aropygrus spp. where they mature until they are ready to shed and penetrate crustacean hosts (Vélez et al., 2003). Neostrengeria macropa (H. Milne Edwards, 1853) is a brachyuran crab native to the Bogotá mountain range that inhabits freshwater areas between 2,200 and 2,900 $\mathrm{m}$ above sea level (Campos, 2005a). $N$. macropa is currently listed as least concern by the IUCN (Cumberlidge, 2008a); however, Campos and Lasso (2015) posit that this species could be vulnerable to human impacts and should be listed as "endangered". Another potential vector is the Louisiana red-clawed crayfish, Procambarus clarkii (Girard, 1852). This invasive species has expanded its range from Mexico and Southeastern United States to other parts of North America as well as South America, Europe, Africa and Asia. P. clarkii is documented to carry Paragonimus spp. in the United States (Procoop, 2009). Invasive crayfish were introduced from aquaculture operations in Colombia (Álvarez-León and Gutiérrez-Bonilla, 2007). These feed on invertebrates, detritus, macrophytes and algae, which drastically alters native food webs through competition between native and invasive crustacean species (Gherardi, 2006). However, there has been no research identifying the ecological impacts or parasites introduced by crayfish in Colombia. Research of direct effects are limited to single species, concentrated on known definitive hosts and narrow geographic location (Lagrue, 2017).
Uruburu et al. (2008) completed a study to identify the prevalence of Paragonimus spp. within nine municipalities of Antioquia, Colombia. This yielded a prevalence of $80.8 \%$. Casas et al. (2008) identified the prevalence rate for Paragonimus spp. to be 55.5\% in Medellin. Lastly, work on the lands inhabited by Emberá ethnic groups within Antioquia resulted in a prevalence of $50 \%$ in crabs and $1.6 \%$ in snails (Vélez et al., 1995; Velez et al. 2003). While human infection rates in Colombia are presently understudied, information about the presence of disease is crucial to estimating the potential risk to vulnerable populations. An example of a local risk factor is "berraquillo", a smoothie-like blend of raw egg, fruit, and live crab consumed as an aphrodisiac in Bogotá, Colombia (all authors, pers. obs.). Based on prevailing risky food practices and poverty, as well as previous studies from Colombia, this study aimed to identify the prevalence of this trematode in crustaceans found in Bogotá (Colombia).

\section{Materials and Methods}

\section{Ethical considerations}

Research on invertebrates is not presently required to have an Institutional Animal Care and Use Committee (IACUC) protocol. Documents for Atlanta Metropolitan State College (AMSC) IACUC for animal use off campus were submitted prior to travel. Permission to conduct research on invertebrates was granted through Universidad Nacional de Colombia, Instituto de Ciencias Naturales. Protocols for relaxation of live animals and dissection were found in previous studies of this parasite and host species (Uruburu et al., 2008).

In June 2015, Neostrengeria macropa $(\mathrm{n}=29$, adult, male $=15$, female $=14$ ) were purchased from Paloquemao, a large food market in Bogotá, Colombia. Based on conversations with the store owner, these animals were collected from streams around Gachancipá, north of the city. Juvenile $P$. clarkii were purchased from a pet store and adults were collected in the wild, also in June, from Club El Rincón de Bogotá golf course $(n=22$, juvenile $=8$, adult $=14$, male $=13$, female $=9$ ). The adults were collected with permission of the land owners using a dip net in a manmade lake on the golf course that frequently floods receiving water from the Bogotá river, where this species was likely introduced from. 
Crayfish and crabs were placed in an ice bath or water chilled to $2{ }^{\circ} \mathrm{C}$ for 10 minutes, after which specimens were measured, and cardiac tissue was removed to ensure cessation of life prior to dissection (Uruburu et al., 2008). Tissues from the heart, hepatopancreas, gill, and large deposits of muscle from claws for both crustacean species, along with abdominal muscle for $P$. clarkii, were placed on slides for examination with stereomicroscopy. From the literature, these tissues were documented to contain metacercariae (Little, 1968; Vélez et al., 2000; Bogitsh et al., 2013). Tissues with metacercariae were placed in $95 \%$ alcohol and transferred to Laboratorio de Parasitología Veterinaria at Universidad de Antioquia for staining. Organs were fixed in 10\% neutral buffered formalin. These samples were then routinely processed and stained with hematoxylin and eosin for histopathological tissue analysis. Due to permit restrictions on genetic analysis for these samples, Paragonimus spp. metacercariae were identified through morphological analysis.

\section{Statistical analysis}

We determined whether the prevalence of Paragoninmus spp. was different from previous findings and a null hypothesis of zero prevalence through Wilcoxon Rank Sum. This non-parametric test was conducted using the statistical package R, with the use of R Commander. Wilcoxon Rank Sum was performed on $N$. macropa to compare our results to the two previous prevalence estimates for Colombia $(\mathrm{mu}=0.555$ and $\mathrm{mu}=0.808)$.

AMaximum Entropy (MaxEnt) Species Distribution Model (version 3.3.3k) was applied using Phillips et al. (2006) and Hudson et al. (2016) as guides. This model uses historical collection data as well as maps of environmental data to predict the probability of geography with similar habitat. The product of this map would help identifying additional collection areas. The environmental layers were downloaded from WorldClim (WorldClim, 2015) for altitude and Bioclim datasets for current data patterns (version 1.3). The data were clipped to the area of interest using the SDMToolbox (version 1.1) within ArcGIS (Version 10.1) and convert raster data downloaded into ASC files to use in the model. The map created contains collection data provided by Prof. Martha H. Rocha de
Campos (Instituto de Ciencias Naturales, Universidad Nacional de Colombia, Bogotá) for N. macropa. Due to the scarce collection data for P. clarkii in Colombia there was not a sufficient number of observations to create a model. It must be noted that due to limitations to do genetic verification in the country, this portion is effectively a map of potential Paragonimus spp. infection for the vector N. macropa in the area.

\section{Results}

Paragonimus spp. was found in both $N$. macropa and P. clarkii (Table 1). Of the market-purchased N. macropa, five of $29(17.2 \%)$ had metacercariae present in tissues. While none of the market-purchased P. clarkii yielded metacercariae, eight of the 14 wildcaught specimens $(57.1 \%)$ yielded metacercariae.

Table 1. Prevalence of Parasites Collected from Crustacean Hosts: "Market" Neostrengeria macropa were purchased from Paloquemao market in Bogotá, Colombia. Procambarus clarkii were purchased from a local pet store designated as market, or were wild-caught from Club El Rincón de Bogotá.

\begin{tabular}{lcc}
\hline & Number of specimens & Paragonimus spp. \\
\hline N. macropa & & \\
Market & 29 & $5(17.2 \%)$ \\
$P$. clarkii & & 0 \\
Market & 8 & $8(57.1 \%)$ \\
Wild-caught & 14 & \\
\hline
\end{tabular}

The prevalence of Paragonimus spp. of $N$. macropa within Bogotá (17.2\%) was significantly different from Casas et al. (2008) at $80.8 \%(\mathrm{p}<0.001$, Wilcoxon Rank Sum) and Uruburu et al. (2008) at $55.5 \%$ ( $<<0.001$, Wilcoxon Rank Sum).

Using MaxEnt, we predicted that potential range for N. macropa is limited to the Bogotá Plain (Sabana de Bogotá) of the Eastern Cordillera mountain range due to lack of connectivity of suitable habitat (Figure 1). Lack of temperate water connecting mountain ranges in Colombia limits range expansion to other areas of suitable habitat. As water temperature exceeds $26^{\circ} \mathrm{C}$, there is a significant decrease in activity of $N$. macropa (Hudson et al. 2016), and therefore it is probably functioning as a vector. 


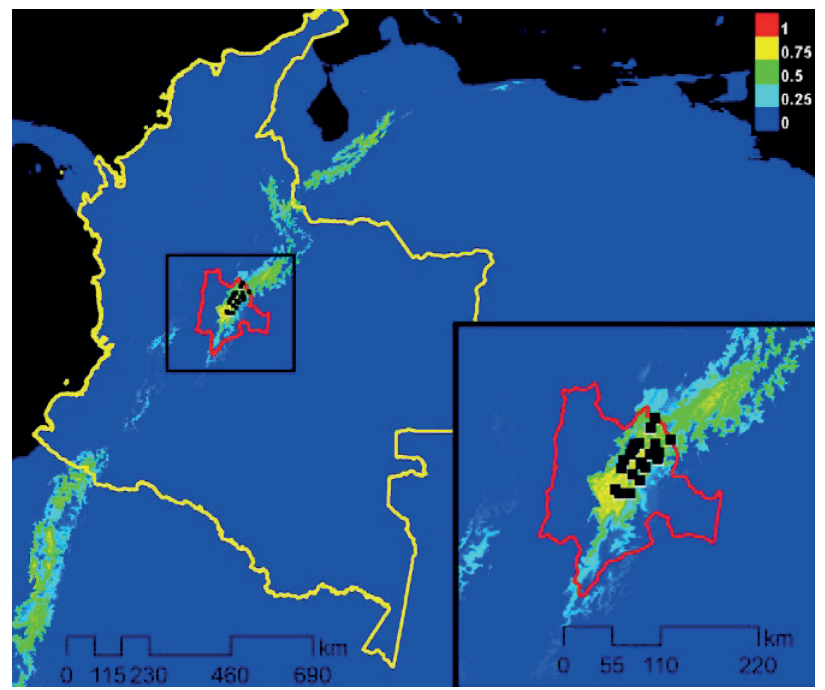

Figure 1. Maximum Entropy Model for the current conditions (Bioclim), and location data of Neostrengeria macropa noted by black dots, in Colombia (yellow line) and Cundinamarca province (red line). The map color represents a probability scale, increasing in probability from blue to red, as to the likelihood of suitable habitat for $N$. macropa.

\section{Discussion}

Both N. macropa and P. clarkii make effective vectors for this genus in the Bogotá Plain. Paragonimus spp. (Figure 2) prevalence in $N$. macropa endemic crabs was $17.2 \%$ (Table 1 ). Though invasive crayfish, $P$. clarkii, purchased from the pet store were not infected, the animals collected at the golf course had a much higher infection rate $(57.1 \%)$ than the native crabs of the Bogota Plain. Paragonimus spp. prevalence in crabs from previous studies in Antioquia (Casas et al., 2008; Uruburu et al., 2008) were significantly higher than the prevalence found in this study $(\mathrm{p}<0.001$, Wilcoxon Rank Sum). Despite this lower incidence rate, results are of public health concern because the specimens from this study were purchased at a local market and are meant for consumption.

Due to the range of $N$. macropa in the Eastern Cordillera mountain range around Bogotá, the range for Paragonimus spp. infection in that species is also narrow. Prediction of the range of $N$. macropa (Figure 2) shows limited range restriction of this species to the Bogotá Plain (Sabana de Bogotá) due

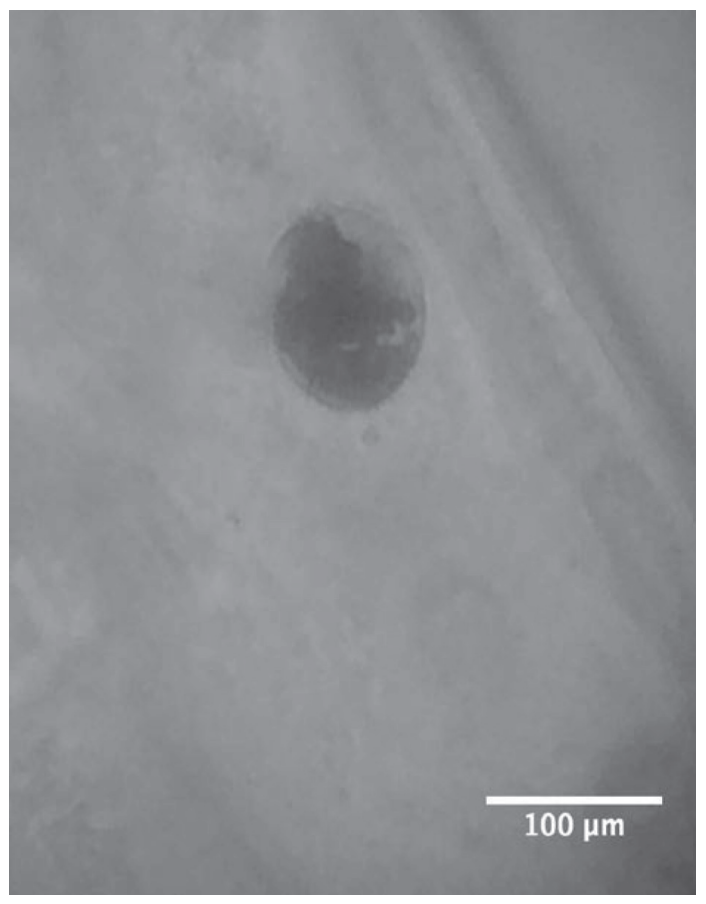

Figure 2. Paragonimus spp identified from $N$. macropa using steromicroscopy. No stain.

to lack of connectivity of suitable habitat. However, this is not restrictive for these trematodes, as there are other freshwater crustaceans that can serve as intermediate hosts throughout the country and that overlap with the range of $N$. macropa (Campos, 2005a).

For Paragonimus spp. to be found in Bogotá, as well as widespread thorough Antioquia, then conduction of this parasite is necessary and could occur though hosts at all stages. Overlap of crustacean species with $N$. macropa and $H$. bouvieri are likely (Campos, 2005a). While the distribution of $N$. macropa is limited (Figure 2), the range of $\mathrm{H}$. bouvieri is large and encompasses much of Colombia as well as Venezuela (Cumberlidge, 2008b). H. bouvieri has been documented to carry Paragonimus spp. in multiple studies in Colombia (Arias et al., 2011; Casas et al., 2008; Vélez et al., 2008). The overlap of habitat ranges could facilitate the spread of this disease.

The role of invasion in providing an additional parasite vectors is prevalent from these results. P. clarkii is clearly an effective vector for Paragonimus spp. and 
therefore may impact other native species. Invasive species can drastically alter the natural food web and the effects of disturbances are greater within freshwater ecosystems when compared to terrestrial ecosystems (Lagure, 2017; Sala et al. 2000). Crayfish are long-lived crustaceans that can survive in high population densities. Introduction of crayfish into other habitats both accidentally and intentionally as a result of cultivation as a food source is a problem due to escapees from aquaculture operations around the world as well as in Colombia (Álvarez-Léon and Gutiérrez-Bonilla, 2007). P. clarkii is invasive in Colombia (Campos and Lasso, 2015), but its distribution in Colombia is unknown. This species is extremely tolerant and can withstand winter temperatures (average high of $-9^{\circ} \mathrm{C}$ ) north of its native range in North America (Gherardi, 2006). This could favour its range expansion into the higher altitudes of the Andes in Colombia.

Abiotic influences between different regions may affect parasitism rates for this species as prevalence from Antioquia and Bogotá are significantly different from each other $(p<0.001$, Wilcoxon Rank Sum). Altitudinal differences between Bogotá $(2600 \mathrm{~m})$ and Medellín (1500 m) may also contribute to differences in parasite prevalence. Other characteristics of lower altitude include warmer temperatures, flatter land, increased vector breeding (Achidi et al., 2008) as well as increased precipitation (Meléndez et al., 2014). Future work should focus on temperature and seasonal aspects of this parasite's life cycle. Temperature differences can also influence parasitic trematodes that have both free-living and hostassociated stages, but vary widely within the group. However, temperature does not seem to affect cercaria development within or emergence from the mollusc host due to the limits of relative size and host resources (Poulin, 2006).

Some Colombian cultural practices, such as consuming "berraquillo", carries an increased human risk of ingesting metacercariae. Food preparation in Bogotá is typically warm or cooked food, such as soup; however, a lack of food knowledge may be reflected in continued practice of "berraquillo" consumption. Two studies conducted interviews of local youth in Antioquia in conjunction with a local university to ascertain food safety knowledge as it relates to crustaceans. The youth were not aware that there was any risk associated with eating raw crabs (Arias et al., 2011; Casas et al., 2008). Areas with lower socioeconomic status as seen in Chocó, Colombia are at higher risk of parasitism as a case study of a seven-year-old girl in this region documents its presence in the region (Múnera et al., 2011). Casas et al. (2008) also voiced concerns about risks within indigenous communities such as the Emberá as well as rural areas. Additional food safety education and potential food regulations need to be implemented to prevent unnecessary adverse human health outcomes.

The authors, and previous reviews, recognize the lack of genetic identification as a limitation of this study. However, previous studies have relied solely on morphology for identification. Future directions for this research will be to expand $N$. macropa and P. clarkii collections to more wildcaught crustaceans as well as snail species and a broader study of genetic information for species identification. Additionally, determining altitudinal and seasonal differences in prevalence would benefit a more comprehensive view of risk. Most importantly, genetic identification is key for species identification. The first report of the presence of Paragonimus sp. in Bogotá, Colombia as well as the host $N$. macropa is important to document due to risky local food practices and lack of knowledge on food safety.

\section{Acknowledgements}

We thank the Georgia State University for International Education Fee scholarship for student travel. A NSF GA-AL LSAMP Grant \#1305041 received by Atlanta Metropolitan State College provided funding for student and professor travels for the completion of this work. We thank Martha Rocha de Campos and the Instituto de Ciencias Naturales, Universidad Nacional de Colombia, Bogotá, Colombia, for expertise, space and support. We thank A. Hudson and D. Mizuta for assistance with translation. We also thank Q. Smith for dissection assistance and support throughout the process. 


\section{Conflicts of Interest}

The authors declare they have no conflicts of interest with regard to the work presented in this report.

\section{References}

Achidi EA, Apinjoh TO, Mbunwe E, Besingi R, Yafi C, Wenjighe Awah N. Febrile status, malarial parasitaemia and gastro-intestinal helminthiases in schoolchildren resident at different altitudes, in south-western Cameroon. Ann Trop Med Parasit 2008; 102:103-118.

Aka N, Adoubryn K, Rondelaud D, Dreyfuss G. Human paragonimiasis in Africa. Ann Afr Med 2008; 7:153-62.

Álvarez-León, R. \& Gutiérrez-Bonilla F de P. Situación de los invertebrados acuáticos

introducidos y transplantados Colombia: antecedentes, efectos y perspectivas. Rev. Acad. Colomb. Cienc. 31 (121):557-574, ISSN 0370-3908.

Arias SM, Salazar LM, Casas E, Henao A, Velásquez LE. Paragonimus sp. En cangrejos y sensibilización de la comunidad educative hacia los ecosistemas acuáticos de La Miel y La Clara, Caldas, Antioquia. Biomédica 2011; 31:209-215.

Bogitsh BJ, Carter CE, Oeltmann TN. Human parasitology. 4th ed. Boston (MA): Academic Press; 2013.

Campos MR and Lasso CA. Libro Rojo de los Cangrejos Dulceacuícolas de Colombia. Instituto de Investigación de Recursos Biológicos Alexander von Humboldt, Intituto de Ciencias Naturales de la Universidad Nacional de Colombia, Bogotá; 2015.

Campos MR \& Rodriguez G. Two new species of freshwater crabs of the genus Phallangothelphusa Pretzmann, 1965 from Colombia (Crustacea: Decapods: Pseudothelphusidae). Proc Biol Soc Washington 1995; 117:35-41.

Campos MR. Freshwater crabs from Colombia. A taxonomic and distributional study. $1^{\text {st }}$ ed. Bogotá: Editora Guadeloupe Ltda; $2005^{\mathrm{a}}$.

Campos MR. Procambarus (Scapulicambarus) clarkii (Girard, 1852), (Crustacea: Decapoda: Cambaridae). Una langostilla no nativa en Colombia. Rev Acad Colomb Cienc Exactas Fish Nat 2005b; 29:295-302.

Campos MR, Pedraza M. Two new species of freshwater crab of the genus Neostrengeria Pretzmann, 1965, from Colombia. Caldasia 2008; 30:1.

Casas E, Gomez C, Valencia E, Salazar L, Velásquez LE. Estudio de foco de paragonimosis en Ruente Clara, Robledo, area periurbana de Medellin, Antioquia. Biomédica 2008; 28:396-403.

Cumberlidge N. Neostrengeria macropa. The IUCN Red List of Threatened Species 2008a: e.T134285A3932048.
Cumberlidge N. Hypolobocera bouvieri. The IUCN Red List of Threatened Species 2008b: e.T134622A3988190.

Davidson RN. Lung and liver flukes. Medicine 2005; 33:68-69.

Gherardi F. Crayfish invading Europe: the case study of Procambarus clarkii. Mar Freshwater Behav Physiol 2006; 39:175-191.

Girard C. A revision of the North American astaci, with observations on their habits and geographic distribution. Proc Acad Nat Sci Philadelphia 1852; 6:87-91.

Hudson D, Brittain V, Phillips G. Behavioral response to temperature change by the freshwater crab Neostrengeria macropa (H. Milne Edwards, 1853) (Brachyura: Pseudothelphusidae) in Colombia. J Crust Biol 2016; 36:287-294.

Kirino Y, Nakano N, Doanh PN, Nawa Y, Horii Y. A seroepidemiological survey for paragonimosis among boarhunting dogs in central and southern Kyushu, Japan. Vet Parasitol 2009; 161:335-338.

Lagrue, C. Impacts of crustacean invasions on parasite dynamics in aquatic ecosystems: A plea for parasite-focused studies. Int J Parasitol 2017; 6:364-374.

Little MD. Paragonimus caliensis sp. $\mathrm{n}$. and Paragonimiasis in Colombia. J Parastiol 1968; 54:738-746.

Liu Q, Wei F, Liu W, Yang S, Zhang X. Paragonimiasis: an important food-borne zoonosis in China. Trends Parastiol 2008; 24:318-323.

Meléndez L, Laiolo P, Mironov S, García M, Magaña O, Jovani R. Climate-driven variation in the intensity of a host-symbiont animal interaction along a broad elevation gradient. PLoS ONE 2014; 9:e101942.

Milne-Edwards H. Memoire sur la famille des Ocypodiens. Ann Sci Nat Zoo 1853; 20:163-228.

Múnera OLM, Ardila NG, Muñoz CAA, Pabón CLR, Gallego LAB, Montoya GMG, Grisales LAG. Paragonimiasis pulmonary en niños: reporte de dos casos. Iatreia 2013; 26 (3): 336-345.

Narain K, Devi KR, Bhattacharya S, Negmu K, Rajguru SK, Mahanta J. Declining prevalence of pulmonary paragonimiasis following treatment \& community education in a remote tribal population of Arunachal Pradesh, India. Indian J Med Res 2015; 141:648-652.

Phillips SJ, Anderson RP, Schapire RE. Maximum entropy modeling of species geographic distributions. Ecol Model 2006; 190:231-259.

Pretzmann G. Vorläufiger Bericht über die Familie Pseudothelphusidae. Denkschr. Osterr Akad Wiss Math Naturwiss Kl 1965; 1:1-11.

Procoop GW. North American Paragonimaisis (Caused by Paragonimus kellicotti) in the Context of Global Paragonimasis. Clin Microbiol Rev 2009: 22:415-46.

Toledo R, Esteban JG, Fried B. Current status of food-borne trematode infections. Eur J Clin Microbiol Infect Dis 2012; 31:1705-18. 
Uruburu M, Granada M, Velasquez LE. Distribucion parcial de Paragonimus en Antioquia, por presencia de metacercarias en cangrejon dulciacuicolas. Biomédica 2008; 28:562-8.

Vélez ID, Ortega J, Hurtado M, Salazar AL. La paragonimosis en al comunidad indígena Emberá de Colombia. Biomédica $1995 ; 27: 51-54$

Vélez AH, Cadavid C, Jaramillo VS, Restrepo H, Angel MA, Pizano JC, Ortega J, Trujillo de P J. El caso de infecciosas
Paragonimiasis pulmonary presentacióon de un case. Med UPB Medellín 2000; 19 (2):149-155.

Vélez I, Velásquez LE, Vélez ID. Morphological Description and Life Cycle of Paragonimus sp. (Trematoda: Troglotrematidae): Causal Agent of Human Paragonimiasis in Colombia. J Parasit 2003; 89:749-755.

WorldClim 2015. Global Climate Data. [Accessed 1 October 2015] URL: http://www.worldclim.org/download

Appendix 1: Location data for Neostrengeria macropa

\begin{tabular}{|c|c|c|c|}
\hline Genus & Species & ${ }^{\circ} \mathbf{N}$ & ${ }^{\circ} \mathbf{W}$ \\
\hline Neostrengeria & macropa & 4.828333 & -73.892500 \\
\hline Neostrengeria & macropa & 5.201944 & -73.738056 \\
\hline Neostrengeria & macropa & 4.961667 & -73.836111 \\
\hline Neostrengeria & macropa & 5.209167 & -73.901389 \\
\hline Neostrengeria & macropa & 5.093889 & -73.994167 \\
\hline Neostrengeria & macropa & 5.093889 & -73.994167 \\
\hline Neostrengeria & macropa & 4.698889 & -73.991389 \\
\hline Neostrengeria & macropa & 5.366667 & -73.783333 \\
\hline Neostrengeria & macropa & 5.046667 & -73.714722 \\
\hline Neostrengeria & macropa & 5.112222 & -73.701111 \\
\hline Neostrengeria & macropa & 5.115000 & -73.744167 \\
\hline Neostrengeria & macropa & 5.096667 & -73.790000 \\
\hline Neostrengeria & macropa & 5.011944 & -73.878333 \\
\hline Neostrengeria & macropa & 5.007778 & -73.880556 \\
\hline Neostrengeria & macropa & 5.161389 & -73.953611 \\
\hline Neostrengeria & macropa & 4.890556 & -73.969444 \\
\hline Neostrengeria & macropa & 5.241389 & -73.579444 \\
\hline Neostrengeria & macropa & 5.066944 & -73.708889 \\
\hline Neostrengeria & macropa & 4.961667 & -73.836111 \\
\hline Neostrengeria & macropa & 4.954722 & -74.082500 \\
\hline Neostrengeria & macropa & 5.197778 & -73.949722 \\
\hline Neostrengeria & macropa & 4.700000 & -74.100556 \\
\hline Neostrengeria & macropa & 5.463056 & -73.743889 \\
\hline Neostrengeria & macropa & 5.143333 & -73.973056 \\
\hline Neostrengeria & macropa & 4.735278 & -74.143889 \\
\hline Neostrengeria & macropa & 5.066944 & -73.708889 \\
\hline Neostrengeria & macropa & 5.040149 & -74.061404 \\
\hline Neostrengeria & macropa & 5.040149 & -74.061404 \\
\hline
\end{tabular}

